\title{
Gas Chromatographic-Mass Spectrometric Analysis of Essential Oil of Jasminum officinale L var Grandiflorum Flower
}

\author{
Feng huan Wei*, Fei long Chen and Xiao mei Tan \\ College of Traditional Chinese Medicine, Southern Medical University, Guangzhou, China, 510515 \\ *For correspondence: Email: awag7674@smu.edu.cn; Tel: +86 20 61648263; Fax: +86 2061648244 \\ Received: 8 September 2014 \\ Revised accepted: 12 December 2014
}

\begin{abstract}
Purpose: To analyze the essential oil composition of the flower of Jasminum officinale L. var. grandifloroum L. (Jasminum grandiflorum) by gas chromatography-mass spectrometry (GC-MS).

Methods: The optimum GC-MS conditions used for the analysis were $250^{\circ} \mathrm{C}$ inlet temperature, $150^{\circ} \mathrm{C}$ MSD detector temperature, and GC oven temperature program as follows: $100^{\circ} \mathrm{C}$ initial temperature, increased to $270^{\circ} \mathrm{C}$ at $4^{\circ} \mathrm{C} / \mathrm{min}$, final temperature $270^{\circ} \mathrm{C}$ and held for $7.5 \mathrm{~min}$.

Results: Thirty compounds were identified, representing $99.28 \%$ of the oil content. The major volatile components of the flower were 3,7,11,15- tetramethyl-2-hexadecen-1-ol (phytol) (25.77\%), 3,7,11trimethyldodeca -1,6,10-trien-3-ol (12.54 \%) and 3,7,11,15- tetramethyl -1-Hexadecen-3-ol (12.42\%). Conclusion: The results show that phytol is the major volatile component of Jasminum grandiflorum.
\end{abstract}

Keywords: Jasminum grandiflorum, Essential oil, Gas chromatography-mass spectrometry

Tropical Journal of Pharmaceutical Research is indexed by Science Citation Index (SciSearch), Scopus, International Pharmaceutical Abstract, Chemical Abstracts, Embase, Index Copernicus, EBSCO, African Index Medicus, JournalSeek, Journal Citation Reports/Science Edition, Directory of Open Access Journals (DOAJ), African Journal Online, Bioline International, Open-J-Gate and Pharmacy Abstracts

\section{INTRODUCTION}

Jasminum officinale L. var. grandiflorum (Jasminum grandiflorum) is one of the Jasminum plants used as a folk remedy for the treatment of hepatitis, dysmenorrhea, stomatitis, duodenitis and depression in south China [1]. There are few reports about its chemical constituents and pharmacological properties, such as the hydroalcoholic extract from the buds of Jasminum grandiflorum showing preferable antiviral efficacy against HBV replication in HepG2 2.2.15 cell line in vitro [2].

Six phenolic compounds have been detected from water-methanol extracts of Jasminum grandiflorum which showed potentials for the treatment of psychiatric disorders and antioxidant protection [3]. Iridoid-type compounds, secoiridoid glucosides, triterpenes, flavonoids, lignans, etc, have also been isolated from this herb [4-6]. Ole (Oleaceae) obtained from the flowers of Jasminum grandiflorum blocked effectively hepatitis B surface antigen secretion in HepG2 2.2.15 cells in a dose-dependent manner $\left(\mathrm{IC}_{50}=23.2 \mathrm{~g} \mathrm{~mL}^{-1}\right)$ while $80 \mathrm{mg} / \mathrm{kg}$ of Ole also reduced viremia in DHBV-infected ducks [7].

Jasminum grandiflorum is aromatic and an excellent source of essential oils. As far as we know, no works on its essential oil analysis has been reported. The objective of this study, therefore, is to evaluate the chemical composition of the flower oil of this plant by GCMS. 


\section{EXPERIMENTAL}

\section{Instruments}

An Agilent 6890N gas chromatography instrument, combined with an Agilent-5973 mass spectrometer equipped with an electron ionization (EI) and quadrupole analyzer, and Agilent Chem Station data system were used. GC separation was performed on a $30 \mathrm{~m}$ DB-5 ms fused silica capillary column with an internal diameter of $0.25 \mathrm{~mm}$ and a film thickness of $0.25 \mu \mathrm{m}$ (Agilent, USA).

\section{Materials and chemicals}

Jasminum grandiflorum (Jasminum officinale L. var. grandifloroum L.) samples (batch no. 201301011, from Heshan City, Guangdong Province, China) were purchased from Guangzhou Kangsheng Pharmaceutical Co, Ltd. All samples were identified by Hongwei Zhang (Associate Professor, Department of Medicinal Plants \& Pharmacognosy, Southern Medical University, Guangzhou, China) according to pharmacognostic standard documented in Vol 1, 2004 edition, Guangdong Province Chinese Medicine Standards [8]. All samples were kept in a desiccator (silica gel as desiccant) at room temperature in Department of Chinese Medicine Pharmaceutics, College of Traditional Chinese Medicine, Southern Medical University, Guangzhou, China, until used. Ethyl acetate was analytical-reagent grade and purchased from reagent company (Guangzhou, China).

\section{Sample preparation}

Jasminum grandiflorum (1 kg) was hydro-distilled for $3 \mathrm{~h}$ in a volatile oil extractor to yield $0.39 \%$ of essential oil. The essential oil obtained was stored in a sealed glass tube with a screw cap in a refrigerator at $4{ }^{\circ} \mathrm{C}$ until analyzed.

\section{Analysis of the essential oil}

The essential oil of Jasminum grandiflorum was subjected to GC-MS analysis system. The carrier gas was helium $(99.99 \%)$ with flow rate of 1.0 $\mathrm{mL} / \mathrm{min}$. Inlet temperature was $250{ }^{\circ} \mathrm{C}$ and MSD detector temperature was $150{ }^{\circ} \mathrm{C}$. Scan range 30 - 550 amu and scan rate of 2 scans/s were used. The GC oven temperature program was used as follows: $100{ }^{\circ} \mathrm{C}$ initial temperature, increased to $270{ }^{\circ} \mathrm{C}$ at $4{ }^{\circ} \mathrm{C} / \mathrm{min}$, final temperature $270{ }^{\circ} \mathrm{C}$ and held for $7.5 \mathrm{~min}$. The analysis period was $50 \mathrm{~min}$. The oil was dissolved in $1 \mathrm{~mL}$ of ethyl acetate and vortex-mixed for $3 \mathrm{~min}$, and finally, $1 \mu \mathrm{L}$ was injected using a split technique (0.2:1). Identification of oil components was achieved based on their retention index, and by comparison of their mass spectral fragmentation patterns with those reported in the literature and stored in the MS library (D.02.00.275, version 2.0d).

\section{RESULTS}

The total ion chromatogram was obtained and showed in Fig 1. Thirty compounds were identified representing approximately $99.28 \%$ of the oil (Table 1). There were significant differences between the main components of the essential oil. The major volatile components were phytol (25.77\%), 3,7,11-trimethyldodeca -1,6,10-trien-3-ol (12.54\%) and 3,7,11trimethyldodeca-6,10-dien-3-ol (12.42\%).

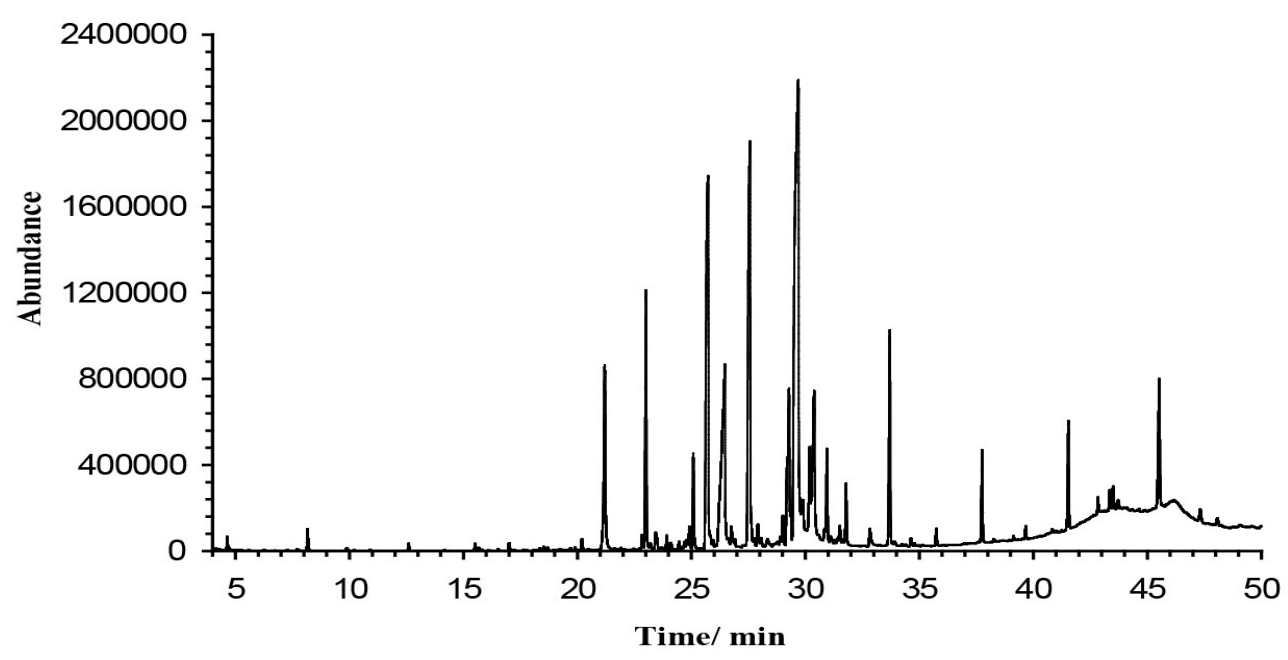

Fig 1: GC-MS total ion chromatogram of essential oil of the flowers of Jasminum grandiflorum 
Table 1: Composition of the flower essential oil of Jasminum Grandiflorum

\begin{tabular}{|c|c|c|c|c|c|}
\hline No. & $\begin{array}{l}\text { Retention } \\
\text { time }\end{array}$ & Component & Formula & Mol wt & $\begin{array}{l}\text { Content } \\
\text { (\%) }\end{array}$ \\
\hline 1 & 8.160 & Benzyl acetate & $\mathrm{C}_{9} \mathrm{H}_{10} \mathrm{O}_{2}$ & 150.17 & 0.33 \\
\hline 2 & 15.516 & Nerolidol & $\mathrm{C}_{15} \mathrm{H}_{26} \mathrm{O}$ & 222.20 & 0.11 \\
\hline 3 & 17.004 & Cedrol & $\mathrm{C}_{15} \mathrm{H}_{26} \mathrm{O}$ & 222.20 & 0.14 \\
\hline 4 & 19.921 & Methyl myristate & $\mathrm{C}_{15} \mathrm{H}_{30} \mathrm{O}_{2}$ & 242.22 & 0.75 \\
\hline 5 & 20.199 & 7-Tetradecene & $\mathrm{C}_{14} \mathrm{H}_{28}$ & 196.22 & 0.20 \\
\hline 6 & 21.195 & Benzyl benzoate & $\mathrm{C}_{14} \mathrm{H}_{12} \mathrm{O}_{2}$ & 212.80 & 4.84 \\
\hline 7 & 22.84 & Neophytadiene & $\mathrm{C}_{20} \mathrm{H}_{38}$ & 278.30 & 0.23 \\
\hline 8 & 23.021 & Perhydrofarnesyl Acetone & $\mathrm{C}_{18} \mathrm{H}_{36} \mathrm{O}$ & 268.28 & 4.85 \\
\hline 9 & 23.928 & Phytol acetate & $\mathrm{C}_{22} \mathrm{H}_{42} \mathrm{O}_{2}$ & 338.32 & 0.22 \\
\hline 10 & 24.467 & Nonadecane & $\mathrm{C}_{19} \mathrm{H}_{40}$ & 268.31 & 0.14 \\
\hline 11 & 24.698 & Geranyl linalool & $\mathrm{C}_{20} \mathrm{H}_{34} \mathrm{O}$ & 290.26 & 0.12 \\
\hline 12 & 25.090 & Methyl palmitate & $\mathrm{C}_{17} \mathrm{H}_{34} \mathrm{O}_{2}$ & 270.26 & 1.57 \\
\hline 13 & 25.736 & 3,7,11,15- tetramethyl -1-Hexadecen-3-ol & $\mathrm{C}_{20} \mathrm{H}_{40} \mathrm{O}$ & 296.31 & 12.42 \\
\hline 14 & 26.465 & Hexadecanoic acid & $\mathrm{C}_{16} \mathrm{H}_{32} \mathrm{O}_{2}$ & 256.24 & 9.16 \\
\hline 15 & 27.573 & 3,7,11-trimethyl-1,6,10-dodecatrien-3-ol & $\mathrm{C}_{15} \mathrm{H}_{26} \mathrm{O}$ & 222.37 & 1254 \\
\hline 16 & 29.014 & $\begin{array}{l}\text { 3,7,11,15-tetramethylhexadecanoic acid methyl } \\
\text { ester }\end{array}$ & $\mathrm{C}_{21} \mathrm{H}_{42} \mathrm{O}_{2}$ & 326.32 & 0.60 \\
\hline 17 & 29.203 & $9,12,15$-octadecatrienoic acid methyl ester & $\mathrm{C}_{19} \mathrm{H}_{32} \mathrm{O}_{2}$ & 292.24 & 1.33 \\
\hline 18 & 29.286 & Heneicosane & $\mathrm{C}_{21} \mathrm{H}_{44}$ & 296.34 & 3.12 \\
\hline 19 & 29.695 & Phytol & $\mathrm{C}_{20} \mathrm{H}_{40} \mathrm{O}$ & 296.31 & 25.77 \\
\hline 20 & 29.897 & Octadecanoic acid methyl ester & $\mathrm{C}_{19} \mathrm{H}_{38} \mathrm{O}_{2}$ & 298.29 & 0.56 \\
\hline 21 & 30.389 & $9,12,15$-Octadecatrienoic acid & $\mathrm{C}_{18} \mathrm{H}_{30} \mathrm{O}_{2}$ & 278.23 & 4.82 \\
\hline 22 & 31.515 & Docosane & $\mathrm{C}_{22} \mathrm{H} 46$ & 310.36 & 0.25 \\
\hline 23 & 33.709 & Tricosane & $\mathrm{C}_{23} \mathrm{H}_{48}$ & 324.38 & 4.00 \\
\hline 24 & 35.746 & Tetracosane & $\mathrm{C}_{24} \mathrm{H}_{50}$ & 338.39 & 0.58 \\
\hline 25 & 37.757 & Pentacosane & $\mathrm{C}_{25} \mathrm{H}_{52}$ & 352.41 & 1.51 \\
\hline 26 & 39.664 & Hexacosane & $\mathrm{C}_{26} \mathrm{H}_{54}$ & 366.42 & 2.54 \\
\hline 27 & 41.533 & Heptacosane & $\mathrm{C}_{27} \mathrm{H}_{56}$ & 380.44 & 1.86 \\
\hline 28 & 43.358 & Octacosane & $\mathrm{C}_{28} \mathrm{H}_{58}$ & 394.45 & 1.26 \\
\hline 29 & 43.501 & Squalene & $\mathrm{C}_{30} \mathrm{H}_{50}$ & 410.39 & 0.46 \\
\hline 30 & 45.523 & Nonacosane & $\mathrm{C}_{29} \mathrm{H}_{60}$ & 408.47 & 3.00 \\
\hline
\end{tabular}

\section{DISCUSSION}

The data show that phytol is the major essential component of Jasminum grandiflorum, and this component may have some of the pharmacological effects of Jasminum grandiflorum plant itself [1]. It was reported that phytol exhibits anticonvulsant activity by modulating of neurotransmitter systems in piloacarpine-induced seizures and showed antitubercular activity against $\mathrm{M}$. tuberculosis H37Rv strain at $100 \mathrm{mg} \mathrm{mL}^{-1}$ (MIC) $[9,10]$. Acute administration of phytol exerts an anxiolytic-like effect on mice by producing sedative and anxiolytic activities [11]. Phytol also directly activates peroxisome proliferator-activated receptor $\alpha$ (PPAR $\alpha$ ) and regulated gene expression involved in lipid metabolism in PPARa-expressing HepG2 hepatocytes [12]. Furthermore, trans-phytol inhibits the biosynthesis of estrogen in human ovarian granulose cells by aromatase (CYP19) [13].

\section{CONCLUSION}

The results reveal that the essential oil of the flower of Jasminum grandiflorum contains thirty compounds in various concentrations, with the major component being phytol.

\section{ACKNOWLEDGEMENT}

We express our appreciation to Associate Professor Hongwei Zhang for identifying the samples and Xiaohua Ye for oil extraction. The work was supported by Science and Technology Planning Project of Guangdong Province, China (no. 2011B032200003) and Science and Technology Planning Project of Guangzhou, China (no. 2012Y2-00018-4).

\section{REFERENCES}

1. Nanjing University of Traditional Chinese Medicine. Dictionary of Chinese Materia Medica 2nd ed. Shanghai: Shanghai Science \& Technology Press, 2006; $p 2476$.

2. Zhao GQ, Yin ZF, Liu LY, Mao XX, Su ZH. Anti-hepatitis $B$ Virus Activity of 8-epi-Kingiside in Jasminum officinale var. grandiflorum. Chinese Herbal Medicines 2013; 1: 53-57.

3. Ferreres $F$, Gross $C$, Gil-Izquierdo $A$, Valentãob $P$, Andrade $P B$. Assessing Jasminum grandiflorum $L$. 
authenticity by HPLC-DAD-ESI/MSn and effects on physiological enzymes and oxidative species. J Pharmaceut Biomed 2014; 88: 157-161.

4. Tanahashi T, Sakai T, Takenaka Y, Nagakura N, Chen CC. Structure elucidation of two secoiridoid glucosides from Jasminum officinale $L$. var. grandiflorum (L.) Kobuski. Chem Pharm Bull 1999; 47: 1582-1586.

5. Somanadhan B, Smitt UW, George V, Pushpangadan $P$, Rajasekharan S, Duus J, Nyman U, Olsen CE, Jaroszewski JW. Angiotensin converting enzyme (ACE) inhibitors from Jasminum azoricum and Jasminum grandiflorum. Planta Med 1998; 64: 246250.

6. Sadhu SK, Khan MS, Ohtsuki T, Ishibashi M. Secoiridoid components from Jasminum grandiflorum. Phytochem 2007; 68: 1718-1721.

7. Zhao GQ, Yin ZF, Dong JX. Antiviral efficacy against hepatitis $B$ virus replication of oleuropein isolated from Jasminum officinale L. var. grandiflorum. J Ethnopharmacol 2009; 125: 265-268.

8. Guangdong Provincial Administration of traditional Chinese Medicine. Guangdong Province Chinese medicine standard Vol. I, Guangzhou: Guangdong Science \& Technology Press, Ltd 2004: 182-184.
9. Costa JP, Ferreira PB, De Sousa DP, Jordan J, Freitas RM. Anticonvulsant effect of phytol in a pilocarpine model in mice. Neurosci Lett 2012; 523: 115-118.

10. Saikia D, Parihar S, Chanda D, Ojha S, Kumar JK, Chanotiya CS, Shanker K, Negi AS. Antitubercular potential of some semisynthetic analogues of phytol. Bioorg Med Chem Lett 2010; 20: 508-512.

11. Costa JP, Oliveira GA de, Almeida AA de, Islam MT, Sousa DP de, Freitas RM de. Anxiolytic-like effects of phytol: Possible involvement of GABAergic transmission Brain Res 2014; 1547: 34-42.

12. Goto T, Takahashi N, Kato S, Egawa K, Ebisu S, Moriyama T, Fushiki T, Kawada T. Phytol directly activates peroxisome proliferator-activated receptor alpha (PPARalpha) and regulates gene expression involved in lipid metabolism in PPARalphaexpressing HepG2 hepatocytes. Biochem Bioph Res Co 2005; 337: 440-445.

13. Guo JJ, Yuan Y, Lu DF, Du BW, Xiong L, Shi JG, Yang LJ, Liu WL, Yuan XH, Zhang GL, Wang F. Two natural products, trans-phytol and (22E)-ergosta6,9,22-triene-3 $\beta, 5 \alpha, 8 \alpha$-triol, inhibit the biosynthesis of estrogen in human ovarian granulosa cells by aromatase (CYP19). Toxicol Appl Pharm 2014; 279: 23-32. 